Article

\title{
Who is More Sustainable? Family Business or Non-Family Business? Czech Evidence
}

\author{
Marie Mikušová ${ }^{1, *(1)}$, Václav Friedrich ${ }^{2} \mathbb{C}$ and Petra Horváthová ${ }^{1}(\mathbb{C}$ \\ 1 Faculty of Economics, Department of Management, Technical University of Ostrava, Sokolská tř. 33, \\ 70100 Ostrava, Czech Republic; petra.horvathova@vsb.cz \\ 2 Faculty of Economics, Department of Mathematical Methods in Economics, Technical University of Ostrava, \\ Sokolská tř. 33, 70100 Ostrava, Czech Republic; vaclav.friedrich@vsb.cz \\ * Correspondence: marie.mikusova@vsb.cz
}

Received: 23 June 2020; Accepted: 2 July 2020; Published: 9 July 2020

check for updates

\begin{abstract}
The aim of this research was to find out whether family businesses create better opportunities for their economic sustainability in comparison with non-family businesses. That is, whether family businesses are more responsible in preparing for crises than non-family businesses. Having a sustainable business means being prepared for potential threats of all kinds. Research was carried out in 2019 on a sample of 2300 family and non-family enterprises. On the basis of statistically processed results, a minimum of significant differences in preparation for the crisis was identified. Even the basic hypothesis about a more responsible approach by family businesses to prepare for the crisis could not be accepted. It could not be noted that family businesses are building better conditions for their economic sustainability. The implication for praxis is to encourage owners to involve the family more in the preparation for crises, including development of formalised tools. Predetermined tools will help in solving crises that threaten the source of livelihoods of the whole family. The comparison of family and non-family businesses in this area, as yet unexplored, has the potential to contribute to the deepening of research in both crisis management and family business, which is the main contribution to the theoretical field.
\end{abstract}

Keywords: preparing for the crisis; family business; sustainability

\section{Introduction}

Czech professional literature and institutions rarely deal with the topic of family business (henceforth FB). What is the cause of delays in theoretical research and practice in this field? The answer must be sought in a political and historical context. The First World War and the subsequent establishment of Czechoslovakia in 1918 were major turning points in the field of family business. The so called "First Republic" brought about many economic changes. Private and family business bloomed. Small manufacturing businesses swelled gradually into successful billionaire business clans, i.e., Bata. Some of the owners became victims of the Nazis, others had their business nationalized after World War II. Throughout the communist era, it was practically impossible to set up a private company. Socialism was the cause of the interruption of the tradition of family business in Czechoslovakia, later the Czech Republic The modern history of family business has been based on the fall of the communist regime in Czechoslovakia in 1989. There have been restitutions and several waves of privatization. Some family businesses that were previously nationalised have been returned to the original owners and still operate today. But there are not many. Family businesses, which today expand on the Czech market and abroad, were formed soon after the "Velvet Revolution" in 1989. In May 2019, the Czech Republic became one of the countries where family businesses are clearly defined. At this time, the government approved the following definition of a family business: family business corporation is a 
business company in which more than $50 \%$ of shareholders is composed of members of one family and at least one member of that family is its statutory body or in which members of one family carry out, directly or indirectly, most voting rights and at least one member of that family is a member of the statutory body of that business corporation.

There is not a single definition of family business which is widely and exclusively applied to every conceivable area, such as to public and policy discussions, to legal regulations, as an eligibility criterion for support services, and to the provision of statistical data and academic research. A very important aspect differentiating family businesses from non-family businesses refers to the element of families or the family culture, the (social) interrelationship between family and enterprise in economic, management and sociological frameworks [1]. Regarding the legislative framework, hardly any consideration of family businesses can be found across Europe. In some of the countries, the term family business is mentioned in different regulations-however, without providing a clarification of what is to be understood by a family business. There are two important elements differentiating family from non-family firms, namely ownership and management/strategic control. Only very few of the identified definitions do not refer to the ownership aspect. In some definitions, this criterion is not specified any further, it is just indicated that the business is to be owned by the family. The majority of analysed definitions refer to a dominant ownership position by requiring a majority of (voting) shares or the ownership of more than $50 \%$ of the shares/capital [2].

Another characteristic used to differentiate family businesses from non-family businesses is the active involvement of family members in the enterprise's everyday activities. Employment of family members is included in about one third of the analysed European definitions of family business [2]. Some of the definitions explicitly use the term 'employment' while others consider family members' 'involvement' or 'activity'. Other definitions also involve the requirement that an enterprise has to generate the main income of the family in order to classify as a family business. In some definitions it is required that different generations have already had control over the business. In Luxembourg, companies that are managed or owned by the second generation are considered as family businesses. Others involve the business owners' intention to pass on the company to the next generation. In some cases, a respective attempt is undertaken by referring to the direct family line or the family unit. A comparatively distinctive approach in this regard can be found in Romania (defining the family as husband/wife, children over 16 years and relatives four times removed) and the United Kingdom (all persons related by blood or marriage). In Belgium, one of the available definitions refers to persons sharing the same surname or living at the same place as the family. This is a way of taking into account more modern ways of living than the traditional family in terms of married couples with children.

It is evident that the definition of family business varies from country to country; however, it always takes into account the number of family members involved in the share capital, the amount of share capital owned by family members, the representation of the family in senior management and, above all, the intention to hand over the business to the successor generation. The most important feature is that the company is based on the founder/personality, the intensity of family involvement in the enterprise, the achievement of quality, which is a prerequisite for success in future generations [3].

The exceptional position of Czech family businesses and their underappreciated importance in research in the Czech environment was the challenge for this research, the partial results of which are presented here. Specifically, this part of the research is focused on the conditions of business economic sustainability.

Sustainability of the business is a strategy that prioritizes the long-term survival of a business [4]. It can be expected that businesses will be subject to increasing competitive pressure and an increasing need for adaptability; there will be often and unexpectedly new dangers and fluctuations in the market to which businesses will have to react quickly if they wish to maintain their prosperity and existence. Support of organizations in a competitive internal market for sustainable and smart growth is also declared by the European Commission (2014/C 249/014). From the above, the authors derived a 
relationship: business economic sustainability equals being prepared for threatening events. So, in this case business sustainability is understood as the preparedness for crisis.

The aim of the research is to find whether family businesses are more responsible in preparing for crises than non-family businesses.

Meeting the stated aim means finding answers to the following research questions:

Research question 1: Are FBs more prepared for crises, so they precede them more often than non-FBs?

Research question 2: If they have experienced a crisis, are FBs more motivated to prepare for crises?

Research question 3: Do FBs consider preparing for a crisis to be more important than non-FBs?

Research question 4: Do FBs care about employees better in times of crisis than non-FBs?

Research question 5: Do the costs of preparing for crises deter them as much as non-FBs?

Research question 6: Do FB managers have time to prepare preventive measures?

Research question 7: Do family and informality prevail even in preparation for crises?

These findings can be done by evaluating the attitudes of owners and managers towards preparation for crisis and identifying possible differences in these attitudes between family and non-family type enterprises. Finally, on the basis of the research results found, whether economic sustainability effort, i.e., being responsible preparing for crises, was greater for family businesses than for non-family businesses.

After identifying the research gap, which is an uncharted area of differences in responsible preparation for crises between FBs and non-FBs, which in turn is a prerequisite for economic sustainability, the research objective was formulated. After the creation of a theoretical base of knowledge, research questions and hypotheses $(\mathrm{H} 1-\mathrm{H} 7)$ were formulated, a sample of respondents was chosen, who were owners or managers of FBs and non-FBs active in the manufacturing industry in all regions of the Czech Republic. The manufacturing industry was chosen because of its participation at the highest level in the production of capital goods. After pre-test and piloting the questionnaire, data collection was carried out using the Computer Aided Web Interviewing (CAWI) method. Of the 8900 respondents surveyed, there was a return of 2300 . After statistical data processing and hypothesis verification, research questions were answered. The reliability of the basis for determining research questions and their answers were submitted for discussion. Suggestions for further research in this area were formulated.

Before further expanding the theoretical basis, the authors intended to better understand the views of the managers and owners themselves. As a way of doing so, the authors chose an informal meeting with fifty owners of family businesses and managers of non-FBs, during which crises, preparation for crises and the elements affecting crisis management were freely discussed. The reason for this informal meeting was that the research outputs are also intended for this group, and also the fact that the authors are not aware of any other comparative research on the subject, not only in the Czech environment. The outputs of this meeting-the opinions of these owners and managers, were very beneficial for the next procedure, especially the creation of a questionnaire (Table A1).

\section{Brief Summary of Contemporary Knowledge and Formulated Hypotheses}

Even after an intensive search, the authors did not find any surveys to which expected results could respond or compare. They therefore took a different approach. They gathered the features of FBs, from which it is theoretically possible to arrive at a different approach of FBs towards preparing for a crisis. These features are declared in a number of research papers, but few are in the context of the crisis and they are even less often compared to non-family businesses in the context of the crisis. Based on these features (and the results of interviews with owners and managers), the authors formulated research questions and hypotheses.

According to the authors, this original approach does not diminish the scientific basis of their research. On the contrary, they believe that by using this approach they have given impetus to further comparative research directly on the individual features listed here in the connection with the crisis 
and preparation for it. In the Discussion section, based on the results identified, it is discussed whether or not the mentioned features contributed to the results of the research.

First of all, the concept of crisis will be clarified. The understanding of crisis is ambiguous. Shrivastava [5] describes a crisis as a breakdown situation characterised by the need for immediate decisions, major adverse impacts and the rebuilding of the system. A crisis is a progressive process which may not be restricted to one area within common borders. It may develop rapidly and emerge with other crises, and its consequences are extended [6]. For the purposes of this research, the crisis is understood (and explained to respondents) as a more or less likely event with major consequences, is perceived by stakeholders as threatening the viability of the organisation, decision-making is under the pressure of lack of time and incomplete information, where the used values, opinions and assumptions are destroyed. Preparing for a crisis that involves shaping teams, plans and developing communicative capabilities is considered to be the core of the management competencies of proactive organization managers [7].

Possible differences in owners' and managers' approaches to crisis prevention will result from the features of family and non-family type enterprises. Inside a family business, there are specific attributes that have the potential to become both an advantage and a disadvantage. Family businesses have distinctive features compared to non-family businesses, which are evident in all areas of operation and will probably also affect access to crisis prevention.

The specific areas of differences between family and non-family businesses, primarily in personnel and economic terms, were found by [8]. After analysing the literature and having meetings with managers and FB owners, the authors created the following groups of features that directly or indirectly affect the willingness and ability to prepare for crises: human resources (intangible aspect of the business), business performance (the resources do not specify what type of performance it is; the term 'business performance' is often used; however, the authors consider that it refers to financial performance) and business resistance during the crisis (tangible and financial aspects) and stakeholders (relationships as an intangible aspect). Issues from these areas are reflected in the questionnaire.

For a clear picture, the relationships are graphically illustrated (Figure 1).

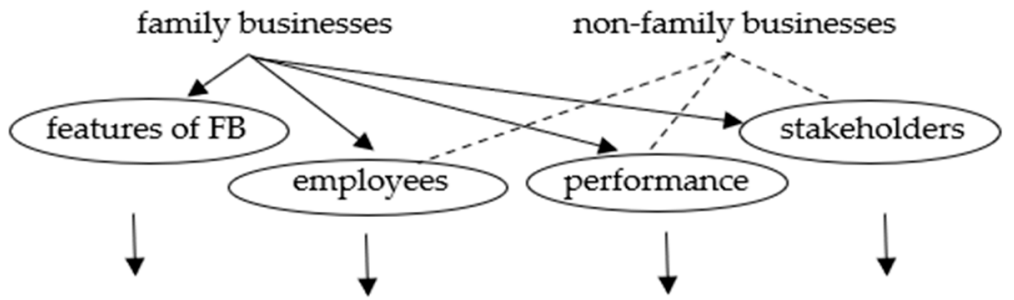

Are FBs more prepared for crises, so they precede them more often than non-FBs?

If they have experienced a crisis, are FBs more motivated to prepare for crises?

Do FBs consider preparing for a crisis to be more important than non-FBs?

Do they care about employees better in times of crisis than non-FBs?

Do the costs of preparing for crises deter them as much as non-FBs?

Do their managers have time to prepare preventive measures?

Does family and informality prevail even in preparation for crises?

Figure 1. Features affecting the ability to prepare for crises and conclusions drawn from them.

Family firms face added complexity regarding human resource management. In contrast with non-family firms, family businesses have many overlapping dimensions of complexity due to the integration of family, business and ownership systems. Family values, vision and purpose are at the centre [9]. In human resources (HR) decisions, a number of family business managers believe they have to choose between family and business [10]. The family-or-business question is the wrong question to ask. It is not an "either-or" but a "both-and." It is necessary to find the approaches that are best for the business and the family [9]. 
This unbalance of family and business interests is reflected through HR practices in the economic outcome [11]. When the family and business are enmeshed, high loyalty can be expected, but HR practices are bifurcated. Family members are strongly favoured, non-family members may perceive injustice when not receiving equal opportunities compared to family members. This leads to relatively low economic outcomes and high non-economic outcomes for the firm.

In contrast to enmeshed family systems, disengaged family systems consist of family members who are not cohesive and have little or no family loyalty. HR practices are not formalized or consistent. Family members are expected to perform at a higher standard than non-family members, family members may suffer from reverse-nepotism. HR practices, such as performance evaluations, are administered which reduces perceptions of fairness and results in relatively moderate economic outcomes and low non-economic outcomes for the firm. When the family system is balanced, bifurcation bias is largely absent in the HR practices and the result is relatively high economic outcomes and moderate non-economic outcomes for the firm [11]. Justice in the HRM process will ensure synergy between family and business. A precondition for this justice is uniform HR policies for non-family as well as family members [12].

The authors of [13] recommend how to use the specifics of a family business for HR management. Their recommendations show the importance of building employee loyalty based on fair access in all HRM areas. It is undeniable that quality care and interest in an employee are closely related to the employee's loyalty which is significantly needed precisely in the tense times of crisis.

The strength of family businesses which could be a great advantage in time of crisis is their socioemotional wealth (SEW). Complex relationships among various socioemotional wealth goals are a frequent subject of the research, e.g., [14,15]. It can be stated that family control and influence, family members' identification with the firm, binding social ties, emotional attachment and renewal of family bonds to the firm through dynastic succession are significant elements that can contribute to the effort to prepare for the crisis and which a non-family company does not have.

Empirical knowledge of the performance of family businesses is diverse. Some authors have confirmed higher performance by family businesses compared to non-family businesses [16]. Conversely, other studies, such as [17], report a negative family impact on business performance. Another different result is presented by the authors of [18] who did not find a significant relationship between family influence and business performance. The fact that the family business is the source of the family's livelihood implies that the family members' management does not like to take risks [19]. Family businesses are rather conservative; they have a higher risk aversion [20]. Thus, they mostly use equity for financing which may result in lower profitability compared to non-family businesses in the same industry, e.g., [21,22]. The question is to what extent the aversion to risk will affect the attitude of the top management towards preparation for crises.

Some scholars note that family businesses perform better during an economic crisis than non-FBs, e.g., [23,24]. However, [25] show a negative effect of family ownership on business profitability, especially during the acute phase of crisis. The responsible approach of the owners of family businesses to investing when they are trying to secure enough liquid resources during a crisis was noted by [26]. The authors of [27] argue that thanks to a higher level of self-funding renewal capacity of family firms, they are better able to cope with a crisis and are more able to absorb shocks such as financial downturns. A similar importance of self-financing of family companies, which is presented in better levels of coverage and liquidity, can be seen in the research of [28]. The argument regarding the better ability of family firms to absorb exogenous shocks is confirmed also by the research of [29]. Additionally, [24] argue that family businesses achieve better performance, have a greater ability to mobilize their resources and are able to adapt their behaviour when a crisis is approaching. The authors of [29] analyse the influence of the ownership structure in declining firms. They found that family-owned businesses with negative financial results tend to maintain the number of employees while they reduce their assets. Business performance during periods of crisis is also influenced by family cohesion and adaptability, e.g., [30-32]. 
Another element influencing business readiness for crisis is the company's relationship with its stakeholders. In their study, [33] concluded that family businesses are more respectful of the rights of stakeholders, unlike non-family businesses whose interest is directed towards shareholders. Communication and interaction with all stakeholders, even to varying degrees, is an important factor for managing crises [34]. Other authors comment on the different perceptions of the position of stakeholders in non-family and family businesses. This difference is perceived as a result of the orientation of the family business to the non-economic, family-oriented aims [35]. A family business combines financial and non-financial goals more than a non-family one. Their managers move towards continuing the business across generations and maximizing the company's long-term value [36]. The aim of non-family businesses is primarily the return on the investment of owners [37]. Does this mean that these fundamentally different objectives impact the preparation for a crisis?

Based on the above, it is apparent that crisis readiness is both directly and indirectly influenced by a number of factors. These factors have been explored in a number of separate research works.

The authors summarise the outputs from mentioned and other studies and formulated research questions and hypotheses:

Families consider their a source of their livelihood. Does this mean that FBs are preparing for crises? Thanks to prevention, the crisis in their business may not occur at all.

Hypothesis 1. Family-owned businesses face crisis situations less often than non-family businesses.

The crisis experienced can lead to a decline in efforts to be proactive (e.g., we were successful, the crisis will not come back).

Hypothesis 2. Having once experienced a crisis situation, FBs are more motivated than non-FBs to improve the preparation process for future crises.

Protecting the source of livelihood is essential.

Hypothesis 3. Family-owned businesses consider preparing to prevent future crises more important than non-family-owned businesses.

Employee-friendly behaviour is often declared in FBs. Is this the case in a crisis?

Hypothesis 4. Family-owned businesses dismiss employees at times of crisis less often than non-family businesses.

The following insights emerged from a meeting with owners and managers: preparing for a crisis makes no sense, because of the following factors.

Hypothesis 5. High costs of implementing measures for preparation for crises is an equally common reason both for family and non-family-owned businesses that do not consider crisis preparation important.

The following insights emerged from a meeting with owners and managers, too: we want to prepare for the crisis, but we are not doing it because...

Hypothesis 6. "Lack of time" is a factor in non-preparation for crisis to the same extent both for FBs and non-FBs.

Informal approaches are generally declared in all FB activities.

Hypothesis 7. Family-owned businesses rely on informal tools in their crisis preparation more than non-family-owned businesses. 


\section{Methodology and Methods of the Research}

The authors' work is based on the assumption that they identified on the basis of the theoretical knowledge that the family character of the business has a strong positive impact on sustainability efforts. So, the need to prepare for the crisis, to take preventive measures to avert and mitigate crisis can be theoretically considered more important by family-owned businesses than by non-family-owned businesses.

\subsection{Analysis of the State of Knowledge}

Through a survey of all databases in Web of Science, the authors found 18,114 records with the topic "family business", including 8806 in the business and economics cluster. Since 2015, there has been an increasing trend in publishing in this area. Researchers in the United States is the biggest contributors to this area (22\%), $0.7 \%$ of results are from the Czech Republic. By specifying advanced keywords, the relevant resources that were used to create an information base for the area under investigation were further found and analysed.

\subsection{Solution Procedure Methodology}

As a starting point, the sector in which the research would be carried out was chosen. The sectors where FBs are most frequently active include agriculture, trading, transport, food, construction and manufacturing industry [38]. For this case, the manufacturing industry was chosen because of its highest participation in the production of capital goods. In the year 2018 it created $2 \%$ gross added value and $27 \%$ of employees were employed in this sector in the Czech Republic. The second step was the decision about the respondents. Respondents come from businesses operating in all regions of the Czech Republic. According to data from the Czech Statistical Office in 2018, 179,567 enterprises operated in the manufacturing industry. To identify non-family businesses, the Companies Database of the Czech Republic was used. It was difficult to identify family businesses because at the time of the research there was no official database of family businesses or a definition of a family business. For the purpose of identification, the researchers utilized the general definition of a family business that includes the aspect of the proportion of family members in the capital and the participation of family members in the management and control of the enterprise. For the present research, the authors have identified that at least one of the following conditions must be met: at least two persons with the same surname are among the owners of the business and/or are in executive or control bodies; or a combination of at least one owner and at least one member in the executive or control body. Thus, the basic set of respondents are managers, executives or owners of business entities operating in the manufacturing industry. When selecting respondents from the official database, it was found that more than one third of companies did not have available information about turnover or number of employees. Many companies do not publish complete financial statements, even if it is their duty. Only companies with available information were included in the selection (i.e., 111,105 enterprises): 106,709 non-family companies and 4396 family companies. All identified family businesses and the same number of non-family businesses were considered for the initial population for sample selection. A random selection of non-family respondents was carried out. The total number of addressees was 8792 respondents. Primary quantitative research was conducted in the spring of 2019 using CAWI. See Appendices for the questionnaire.

In the creation of the questionnaire, the authors relied on literature review and the conclusions of the meeting with FB owners and non-FB managers (see Introduction). The invitation to a meeting was accepted by managers and business owners mainly from the Moravia region. The meeting was arranged in such a way as to represent both production and service undertakings, as well as enterprises of different sizes in terms of number of employees and annual turnover. 
The authors consider the linking of outputs from previous research and theoretical knowledge with practical experience transmitted face-to-face as very beneficial not only for the creation of a questionnaire.

When creating the questionnaire, its psychometric characteristics were taken into account. The questionnaire was anonymous and was implemented by the CAWI method. This ensured that there were no possible conflicts of interest or the possibility of data distortions by the researchers; the results were not dependent on the persons who analysed them. This ensured the objectivity.

In order to make the questionnaire clear enough to provide the required data, experts from universities were consulted regarding the content validity. Item-level content validity index (I-CVI) was used for the purpose of clarity. The I-CVI expresses the proportion of agreement on the relevancy of each item, which is between zero and one. A panel of eight content experts were asked to rate each scale item (21 items) in terms of its relevance to the underlying construct (Table 1).

Table 1. Ratings on a 21-item scale by eight experts: Items rated 3 or 4 on a 4-point relevance scale (abbreviated sample).

\begin{tabular}{ccccccc}
\hline Items & Expert 1 & Expert 2 & Expert 3 & Expert 8 & Number in Agreement & Item CVI \\
\hline Item 1 & $\mathrm{x}$ & $\mathrm{x}$ & $\mathrm{x}$ & $\mathrm{x}$ & 6 & 0.75 \\
Item 2 & $\mathrm{x}$ & $\mathrm{x}$ & - & $\mathrm{x}$ & 8 & 1 \\
$\cdot$ & $\cdot$ & $\cdot$ & $\cdot$ & $\cdot$ &. &. \\
$\cdot$ & $\cdot$ & $\cdot$ &. &. & 8 &. \\
Item 21 & $\mathrm{x}$ & $\mathrm{x}$ & $\mathrm{x}$ & $\mathrm{x}$ & Mean I-CVI & 0.9 \\
$\begin{array}{c}\text { Proportion } \\
\text { relevant }\end{array}$ & 0.9 & 0.9 & 0.9 & 1 & Mean expert proportion & 0.9 \\
\hline
\end{tabular}

Item 1: Have you experienced a crisis, i.e., an event that endangered the existence of your business? Item 2: What impact has the crisis had on your business? (reduce the number of employees). Item 21: To what extent has your organization created the following conditions for coping with crises? (we know about external threats-competition, market, legislation, distribution, and the like). Ratings of 1: not relevant; 2: somewhat relevant. Rating of 3: quite relevant; 4 : highly relevant.

The mean I-CVI is 0.9. When there are six or more judges, Lynn recommends I-CVIs no lower than 0.78 [39].

The validity was also evaluated by representatives of future respondents. In cooperation with fifteen FB owners and fifteen non-FB managers (about half of them participated in a previous meeting, the other half were approached because of a broader view of the issue and its comprehensibility).

The content validity was evaluated using the content validity ratio (CVR) [40]:

$$
C V R=\frac{E-\frac{N}{2}}{\frac{N}{2}}
$$

where $N$-total number of panellists; $E$-the number who rated the object as essential.

This formula yields values which range from +1 to -1 ; positive values indicate that at least half the panelists rated the item as essential. The mean CVR across items may be used as an indicator of overall test content validity [40].

The final form of the questionnaire consists of four main topics (experience with the crisis, assessing the importance of preparing for the crisis, why it is useless to prepare for a crisis, items to prepare for crises) and 21 items.

The content validity ratios ranged between 0.87 and 1.00 for each topic, ranging from 0.67 to 1.00 for each item. According to Lawshe, the minimum value of $C V R$ for thirty panellists is 0.33 (one-tailed test, $p=0.05$ ) [40]. The condition for contend validity is therefore fulfilled in both cases.

Sufficient reliability is a prerequisite for a good validity of the questionnaire. To determine reliability using the split-half method, the authors followed the Kline rule, i.e., the reliability of the method should be at least 0.7 [41]. 
The split-half reliability method involves splitting a test into halves and correlating examinees' scores on the two halves of the test. The resulting correlation is then adjusted for test length using the Spearman-Brown prediction formula [42]:

$$
\mathrm{p}_{\mathrm{xx}}^{\prime}=\frac{2 p_{12}}{1+p_{12}}
$$

where $p_{12} \rho 12\left\{\backslash\right.$ displaystyle $\left.\{\backslash \text { rho }\}_{-}\{12\}\right\}$ is the Pearson correlation between the split halves; $\mathrm{p}_{x x^{\prime}}$ is the reliability of the current test.

Reliability exceeded 0.7 and therefore the questionnaire was eligible to obtain valuable data.

The questionnaire was formulated to be as short and simple as possible to break the general reluctance of entrepreneurs to respond to such questionnaire activities but at the same time to obtain valuable data. After design of the questionnaire, a finishing pre-test with five persons from the target group was done. These managers or owners did not participate in the previous meeting. They were asked about their general impressions, any problematic questions, and so on. This was done face-to-face to see the reaction of respondents. For the pilot surveys a sample of thirty respondents from target group was enough. The pilot test took place in the same way as the expected full test, i.e., sending emails with a link to an online questionnaire with the possibility of commenting on individual items. Based on evaluations and tests, minor changes were made to the formulations and a regulatory investigation could be triggered.

Data were processed using statistical methods. Using statistical tests, relationships between variables were tested, analysis was performed.

To measure the attitude of family and non-family companies towards preparing for the crisis, a six-point Likert scale with the following levels was used: $1=$ definitely not, $2=$ mostly not, $3=$ rather not, $4=$ rather yes, $5=$ mostly yes, $6=$ definitely yes. The purpose of scaling is to assign specific numerical values to different levels of the examined attitudes so that they can be further evaluated and compared using statistical tools [43]. The Likert scale is symmetrical, containing the same number of positive and negative attitudes. The distances between the individual values of the scale are perceived by respondents as the same. In this research a scale with six values was used to prevent respondents from taking neutral attitudes on measured issues.

Two types of tests can be used to compare the attitudes of family and non-family companies:

- a parametric two-sample $t$-test;

- a nonparametric Pearson's chi-square independence test.

The null hypothesis $\mathrm{H}_{\mathrm{a}}$ in both types of tests represents identical attitudes (statistically insignificant differences), the alternative hypothesis $\mathrm{H}_{\mathrm{b}}$ corresponds to different attitudes in both groups compared.

The $t$-test compares the average attitudes calculated as arithmetic means of the scale values for both family and non-family companies.

The test statistic for the two-sample $t$-test is defined by the formula

$$
t=\frac{\overline{x_{1}}-\overline{x_{2}}}{\sqrt{\frac{s_{1}^{2}}{n_{1}}+\frac{s_{2}^{2}}{n_{2}}}}
$$

where $\overline{x_{1}}$ and $\overline{x_{2}}$ are average values (sample means) in both groups, $s_{1}$ and $s_{2}$ are sample standard deviations, $n_{1}$ and $n_{2}$-sample sizes (numbers of values).

If the null hypothesis $\mathrm{H}_{\mathrm{a}}$ is valid, the test statistics $t$ has Student's $t$-distribution with

$$
\mathrm{df}=\mathrm{n}_{1}+\mathrm{n}_{2}-2
$$

degrees of freedom. 
The chi-square independence test compares the distribution of frequencies of individual values in the attitudes of family and non-family companies. The test statistic for the chi-square test of independence is defined by the formula

$$
G=\sum_{i=0}^{n} \sum_{j=0}^{n} \frac{\left(n_{i j}-e_{i j}\right)^{2}}{e_{i j}}
$$

where $n_{i j}$ represents objected (measured) counts and $e_{i j}$ are "expected" counts. The first index $i$ represents individual points of the Likert scale (1-6), the second index $j$ distinguishes both compared groups ( $j=1$ for non-family companies, $j=2$ for family ones).

In the case of a valid null hypothesis $\mathrm{H}_{\mathrm{a}}$ the test statistic $G$ has Pearson's distribution with $d f=3$ degrees of freedom. Given the large number of cases, the "quantitative" approach using a parametric $t$-test is legitimate, see [43]. As reported by [43], the results of both kinds of tests (parametric and non-parametric) are comparable. Therefore, outputs of both tests are presented only for one comparison in this article; in other cases, only results of two-sample $t$-tests are presented.

For the statement verification, factor analysis was used as an independence technique in which there is no dependent variable. The motivation behind the factor analysis is the fact that often there are many variables involved in a research design, and it is usually helpful to reduce the variables to a smaller set of factors, aiming mainly to understand the underlying structure of the data matrix. The relationship of each variable with the underlying factor is expressed by the factor loading. In the parametric approach, the independent variables are usually assumed to be normal and continuous, with at least three to five variables loading onto a factor. The sample size should be large (i.e., the number of observations should be greater than 50), with at least five observations per variable. Principal component analysis, which extracts factors based on the total variance of the factors, was used. Principal component analysis is used to find the smallest number of variables that explain the most variance, whereas common factor analysis is used to look for the latent underlying factors. Usually the first factor extracted explains most of the variance. The factor loadings express the correlations between the variables and the factor. As a rule of thumb, a factor loading of at least 0.4 strongly suggests that a specific variable can be attributed to a factor [43].

\subsection{Representation Results of the Tests}

The results of both $t$-tests and chi-square tests are presented by $p$-value (significance) and sign scheme. A $p$ value greater than 0.05 means that the null hypothesis $\mathrm{H}_{0}$ cannot be rejected (identical attitudes). In contrast, $p<0.05$ means that the null hypothesis $\mathrm{H}_{0}$ is rejected and the alternative hypothesis $\mathrm{H}_{\mathrm{b}}$ is accepted (different attitudes).

The power of significance of the accepted alternative hypothesis can be expressed using a sign scheme. The + to +++ signs represent a significant difference in attitude in favour of non-family companies, while the - to --- signs indicate a significant attitude in favour of family companies. Sign 0 represents no significant difference, i.e., the null hypothesis $\mathrm{H}_{\mathrm{a}}$ is not rejected.

\section{Results of the Research}

A total of 2266 respondents were considered for the results of the research: 1118 (49.3\%) non-family companies and 1148 (50.7\%) family companies.

\subsection{Characteristics of the Surveyed Enterprises}

Most of the companies have an annual turnover of CZK 5-20 million (443 non-FB and 479 FB). Regarding breakdown by staff numbers, most respondents were in the up-to-50-employees bracket. Specifically, this applied to $79 \%$ of the non-family-owned businesses and $91 \%$ of family-owned businesses. Only $1 \%$ of non-family-owned businesses stated that they have over 500 employees. There were no family-owned businesses with over 500 employees. 
As noted in the Introduction section of this article, there are considerations specific to post-communist countries in the historical context. A sharp rise in private business creation following the "Velvet Revolution" in November 1989 is apparent (see Figure 2). The 1990s opened the floodgates for Czechoslovakian (later Czech) entrepreneurs and private business creation. At the same time, this presented opportunities for conmen who abused the relative immaturity of the market and people's inexperience in the private sector. The sharp decline in new business creation following 2010 can be attributed to the global financial crisis. In addition to the financial crisis fallout, there were heightened administrative requirements for entrepreneurs introduced in 2015 which also contributed to lowered appetite for business creation. It is noted, however, that the previously mentioned new administrative requirements reflect those established in surrounding countries and the resentment was rather media-created.

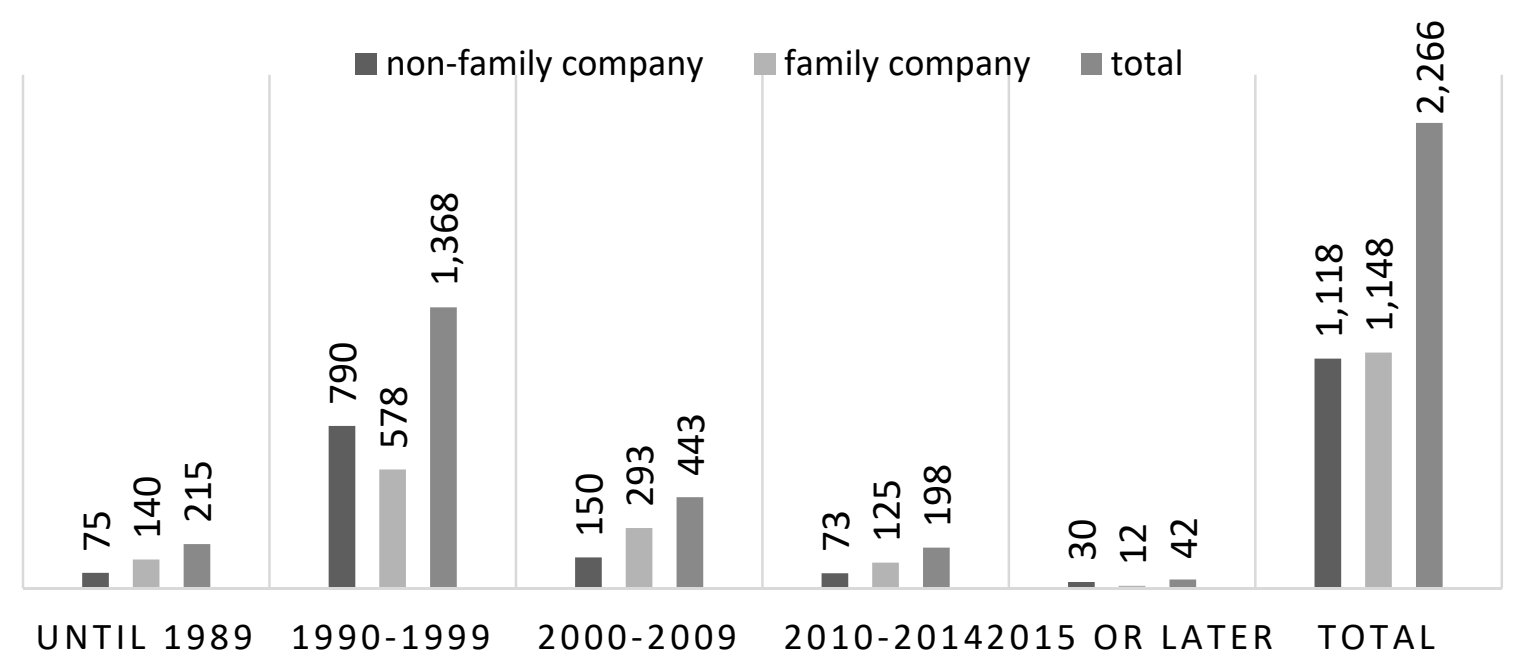

Figure 2. Year of establishment.

The authors would like to highlight that business founders of enterprises created post 2015 (and often even post 2010) are often unsure whether they are able to designate their business as family-owned.

\subsection{Hypothesis 1}

The first part of the questionnaire focused on finding out how enterprises perceive crises.

4.2.1. Have You Experienced a Crisis, i.e., an Event that Endangered the Existence of Your Business?

Hypothesis 1a. Family-owned businesses face crisis situations to the same extent as non-family businesses.

Hypothesis 1b. Family-owned businesses face crisis situations less frequently than non-family businesses.

Only $13 \%$ of non-family-owned businesses (147 respondents) and $15 \%$ of family-owned businesses (178) are certain they have not had to face a situation which threatened the existence of their organization yet. On the other hand, 39\% of non-family-owned businesses (440) and 38\% of family-owned business (434) openly admit they have gone through such a crisis already.

Overall, $63 \%$ of all respondents (across both family-owned and non-family-owned) have definitely not or rather not come across a business threatening situation yet.

An average score ( $1=$ definitely not, $6=$ definitely yes $)$ and testing the difference between family and non-family companies are in Table 2 . 
Table 2. Have you experienced a crisis, i.e., event that endangered the existence of your business?

\begin{tabular}{|c|c|c|c|c|c|c|}
\hline \multicolumn{3}{|c|}{ Type of Enterprise } & \multicolumn{2}{|c|}{ Pearson $\chi^{2}$ Independence Test } & \multicolumn{2}{|c|}{ Comparison of Means $t$-Test } \\
\hline & Non-FB & FB & Pearson's chi-square & 4.687 & $t$ statistics & 0.201 \\
\hline & & & $p$-value & 0.196 & $p$-value & 0.841 \\
\hline Mean & 2.86 & 2.87 & sign & 0 & sign & 0 \\
\hline Std. deviation & 1.08 & 1.09 & $\mathrm{~N}$ of valid cases & 2266 & $\mathrm{~N}$ of valid cases & 2266 \\
\hline
\end{tabular}

\subsubsection{Conclusions}

There was no significant difference in the application of crisis management between family and non-family-owned businesses. The null hypothesis (Family-owned businesses face crisis situations to the same extent as non-family-businesses) is accepted as based on the results, the attitudes and responses are identical attitudes.

Hypothesis 1-Family-owned businesses face crisis situations less frequently than non-family businesses-is rejected.

\subsection{Hypothesis 2}

The authors were interested in the extent to which the experienced crisis has motivated businesses to prepare for a crisis in the future.

4.3.1. Has the Crisis Situation You Went Through Made You Ready to Cope with Potential Future Crises (i.e., by Developing Variants of Decisions, Reserve Plans, Crisis Plans, Establishing Contacts with Problem Management Experts, etc.)?

Hypothesis 2a. Having once experienced a crisis situation, FBs are motivated to the same extent as non-FBs to improve the preparation process for future crises.

Hypothesis $\mathbf{2 b}$. Having once experienced a crisis situation, FBs are more motivated as non-FBs to improve the preparation process for future crises.

The results show that overall, once a crisis has been experienced, businesses do tend to make preparations to prevent future crises ( $72 \%$ of non-FBs and $74 \%$ of FBs). It is noted, however, that non-family-owned business are less definite in their responses than family-owned businesses, as only $26 \%$ state they have definitely been influenced (definitely yes) in their future decisions regarding crisis prevention, compared to $48 \%$ who responded that they are rather inclined (rather yes) to take future preventive measures as a result of the past crisis. This is in contrast to family-owned-businesses where the responses are more balanced with $36 \%$ stating the more hesitant responses (rather yes, mostly yes) as well as the same amount of responses, $36 \%$ providing a definite answer (definitely yes). An average score and testing the difference are in Table 3.

Table 3. Has the crisis situation you went through made you ready to cope with potential future crises?

\begin{tabular}{cccccc}
\hline \multicolumn{2}{c}{ An Average Score (1 = Definitely Not, $\mathbf{6}=$ Definitely Yes) } & \multicolumn{2}{c}{$\begin{array}{c}\text { Testing the Difference between Family } \\
\text { and Non-Family Companies }\end{array}$} \\
\cline { 1 - 2 } Non-Family Company & Family Company & & $t$ statistics & -1.030 \\
Std. Deviation & 2.93 & 3.02 & & -value & 0.304 \\
& 0.84 & 0.92 & & sign & 0 \\
& & & N of valid cases & 1417 \\
\hline
\end{tabular}




\subsubsection{Conclusions}

There was no significant difference in preparation for future crises between family and non-family companies. The null hypothesis (Family-owned businesses and non-family-owned businesses which had experienced a crisis prepared for future crisis situations to the same extent afterwards) is accepted due to identical attitudes.

Hypothesis 2-Having once experienced a crisis situation, FBs are more motivated than non-FBs to improve the preparation process for future crises-is rejected.

The authors performed an assumptions test in order to confirm or disprove the link between the past crisis and the subsequent prevention measures put in place:

$n$ sample file (number of businesses that had experienced a crisis);

$m$ (number of businesses that subsequently started to put preventive measures in place); $1.645\}$;

$p_{0}($ relative frequency $)=70 \%$, i.e., 0.7 , level $=0.05$, critical field $\mathrm{W}=\mathrm{W}_{0.05}=\left\{\mathrm{U} \geq \mathrm{u}_{0.95}\right\}=\{\mathrm{U} \geq$

As the authors are not aware of similar research for the comparison, they themselves set a limit of relative frequency of 0.7 ;

H2a: At least $70 \%$ of FBs that had experienced a crisis will put measures in place to prevent a future one ( $p=p_{0}$ the assumption equals reality);

$\mathrm{H} 2 \mathrm{~b}\left(p \neq p_{0}\right.$ the assumption differs from reality).

Test criterion for the relative frequency test:

$$
U=\frac{\frac{m}{n}-p_{0}}{\sqrt{\frac{p_{0}\left(1-p_{0}\right)}{n}}}
$$

$U=1.647\{U \geq 1.645\}$

It can be stated that over $70 \%$ of family-owned businesses that had experienced a crisis, will subsequently put measures in place to prevent a future crisis.

The same statement can be made for non-family-owned businesses which also corresponds with the results of the relative frequency $p_{0}=0.71(U=1.705)$. This difference also confirms the aforementioned insignificance of difference in preparation for future crises.

\subsection{Hypothesis 3}

The below hypothesis (3) was formulated for this part of the research.

\subsubsection{Do You Consider Preparing for Crises Important?}

Hypothesis 3a. Family-owned businesses consider preparing to prevent future crises important to the same extent as non-family-owned businesses.

Hypothesis $\mathbf{3 b}$. Family-owned businesses consider preparing to prevent future crises more important than non-family-owned businesses.

The complete predominance of a positive attitude towards the importance of preparing for crises has been identified. Only 1.6\% of FB and non-FB replied unequivocally answered with "definitely

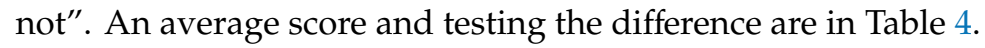


Table 4. Do you consider preparing for crises important?

\begin{tabular}{|c|c|c|c|c|}
\hline \multicolumn{3}{|c|}{ An Average Score (1 = Definitely Not, 6 = Definitely Yes) } & \multirow{2}{*}{\multicolumn{2}{|c|}{$\begin{array}{l}\text { Testing the Difference between Family } \\
\text { and Non-Family Companies }\end{array}$}} \\
\hline & Non-Family Company & Family Company & & \\
\hline Mean & 3.34 & 3.21 & $t$ statistics & 2.638 \\
\hline Std. Deviation & 0.71 & 0.77 & $\begin{array}{c}p \text {-value } \\
\text { sign } \\
\mathrm{N} \text { of valid cases }\end{array}$ & $\begin{array}{c}0.008 \\
++ \\
2266\end{array}$ \\
\hline
\end{tabular}

Source: own research.

\subsubsection{Conclusions}

There was a highly significant difference between family and non-family companies for the benefits of non-family companies. The authors' assumption that family-owned businesses tend to take more interest in how to decrease the vulnerability of their business in order to ensure the family name stays on the market and can be passed down to future generations has had to be rejected.

Hypothesis 3-Family-owned businesses consider preparing to prevent future crises more important than non-family-owned businesses do-is rejected.

\subsection{Hypothesis 4}

The next part of the questionnaire focused on the impact the past crisis experience has had on the business. The hypothesis is based on the claim by some researchers in the Section 2 of previous text that family businesses are laying off their employees in times of crisis as a last resort to reduce costs.

\subsubsection{What Impact has the Crisis Had on Your Business?}

Hypothesis 4a. Family-owned and non-family-owned businesses dismiss employees at times of crisis to the same extent.

Hypothesis $\mathbf{4 b}$. Family-owned businesses dismiss employees at times of crisis to the less often as non-family businesses.

A significant difference between non-family and family businesses was found: decrease in sales (important) and loss of business partners (very important). In both cases, a higher impact on family businesses was found. There was no significant difference in "the reduction of the number of employees at the time of crisis" between family and non-family businesses (see Table 5).

Table 5. What impact has the crisis had on your business? Comparison using average scale values.

\begin{tabular}{cccccc}
\hline & \multicolumn{2}{c}{ Means (Type of Enterprises) } & \multicolumn{1}{c}{$\boldsymbol{t}$-Test for Equality of Means } \\
\cline { 2 - 6 } & $\begin{array}{c}\text { Non-Family } \\
\text { Company }\end{array}$ & $\begin{array}{c}\text { Family } \\
\text { Company }\end{array}$ & $\boldsymbol{t}$ Stat & $\boldsymbol{p}$-Value & Sign \\
\hline Reduce the number of employees & 2.63 & 2.51 & 1.308 & 0.191 & 0 \\
Decrease sales (income) & 3.11 & 3.25 & -2.122 & 0.034 & - \\
Divestment of own assets & 1.27 & 1.33 & -1.225 & 0.221 & 0 \\
Loss of business partners & 2.40 & 2.61 & -2.770 & 0.006 & - \\
\hline
\end{tabular}

Source: own research.

\subsubsection{Conclusions}

The null hypothesis (Family-owned and non-family-owned businesses dismiss employees at times of crisis to the same extent) is accepted based on the results as the attitudes are comparably identical. 
Hypothesis 4-Family-owned businesses dismiss employees at times of crisis less often as non-family businesses-is rejected.

\subsection{Hypothesis 5}

The next step in the research was to establish what leads businesses to the believe that preparations to prevent future crises are not important.

\subsubsection{Why do You not Consider Preparing for Crises Important?}

Hypothesis 5a. High costs of implementing measures for preparation for crises is an equally common reason both for family and non-family-owned businesses that do not consider crisis preparation important.

Hypothesis $\mathbf{5 b}$. High costs of implementing measures for preparation for crises is not an equally common reason both for family and non-family-owned businesses that do not consider crisis preparation important.

Comparison using average scale values is in Table 6. Responses are the options from the questionnaire (see Table A1).

Table 6. Why do you not consider preparing for crises important? Comparison using average scale values.

\begin{tabular}{cccccc}
\hline \multirow{2}{*}{ Response } & \multicolumn{2}{c}{ Means (Type of Enterprises) } & \multicolumn{2}{c}{$\boldsymbol{t}$-Test for Equality of Means } \\
\cline { 2 - 6 } & $\begin{array}{c}\text { Non-Family } \\
\text { Company }\end{array}$ & $\begin{array}{c}\text { Family } \\
\text { Company }\end{array}$ & $\boldsymbol{t}$ Stat & $\boldsymbol{p}$-Value & Sign \\
\hline Preparation is too expensive & 2.71 & 2.63 & 0.558 & 0.191 & 0 \\
It will not prevent the crisis anyway & 2.80 & 2.53 & 1.961 & 0.051 & 0 \\
Crisis cannot be predicted & 2.70 & 2.66 & 0.310 & 0.757 & 0 \\
We are not afraid of a crisis & 2.48 & 2.19 & 2.064 & 0.040 & + \\
\hline
\end{tabular}

\subsubsection{Conclusions}

There was no significant difference in the "preparation is too expensive" response between family and non-family-owned businesses. The null hypothesis of high costs of implementing measures for preparation for crises is a reason stated equally by both family and non-family-owned businesses that do not consider preparations for crises important. H5a, therefore, is accepted.

A significant difference between non-family and family businesses was found in the reason "not being afraid of a crisis". A higher impact on non-family businesses was found. Non-FBs are convinced they have a strong market position, strong strategic partner(s), healthy finances, etc. However, as history tells us, a number of businesses with such a mindset succumbed to crises.

Businesses often twist reality so that it suits their beliefs. Managers are able to make convincing arguments about the situation being "business-as usual-type issues" and not an impending crisis.

Authors of [44] present a number of faulty assumptions and beliefs held by businesses, e.g., size of the business (too big to fail), perfection (well-run businesses do not experience crises), reaction (it is enough to act only once the crisis happens), unpredictability (crises cannot be predicted and therefore one cannot prepare for them), immunity (crises only happen to others), cost (crisis management is too expensive), the goal justifies the means (the end goal of business justifies highly risky means and actions), etc.

Hypothesis 5-High costs of implementing measures for preparation for crises is an equally common reason both for family and non-family-owned businesses that do not consider crisis preparation important-is accepted. 


\subsection{Hypothesis 6}

The next research question focused on businesses that admit the importance of preparation for crises but do not implement any crisis prevention measures because.

4.7.1. What Prevents You (i.e., Causes Complications) from Preparing for Coping with a Crisis?

Hypothesis 6a. "Lack of time" is a factor for non-preparation for crisis to the same extent both for FBs and non-FBs.

Hypothesis 6b. "Lack of time" is not a factor for non-preparation for crisis to the same extent for both FBs and non-FBs.

The respondents considered lack of necessary experts, finance or time. There was no significant difference between family and non-family companies (see Table 7). Responses are the options from the questionnaire (Table A1).

Table 7. What prevents you (i.e., causes complications) from the preparation for coping with a crisis? Comparison using average scale values.

\begin{tabular}{cccccc}
\hline \multirow{2}{*}{ Response } & \multicolumn{2}{c}{ Means (Type of Enterprises) } & \multicolumn{2}{c}{$\boldsymbol{t}$-Test for Equality of Means } \\
\cline { 2 - 6 } & $\begin{array}{c}\text { Non-Family } \\
\text { Company }\end{array}$ & $\begin{array}{c}\text { Family } \\
\text { Company }\end{array}$ & $\boldsymbol{t}$ Stat & $\boldsymbol{p}$-Value & Sign \\
\hline Lack of necessary experts & 2.62 & 2.64 & -0.252 & 0.801 & 0 \\
Not enough money & 2.58 & 2.67 & -0.949 & 0.343 & 0 \\
No time to deal with the & 2.78 & 2.89 & -1.289 & 0.198 & 0 \\
Preparation & & & & & \\
\hline
\end{tabular}

Source: own research.

\subsubsection{Conclusions}

The null hypothesis ("Lack of time" is a factor for non-preparation for crisis to the same extent for both for FBs and non-FBs) cannot be rejected (identical attitudes). Being overwhelmed with operational activities ("no time to deal with crisis preparation") was a reason declared by smaller businesses which is logical.

Hypothesis 6-Lack of time is a factor for non-preparation for crisis to the same extent both for FBs and non-FBs-is accepted.

\subsection{To be Proactive Business?}

The next research question was geared towards businesses proactive in crisis preparations (see Figure 3). 


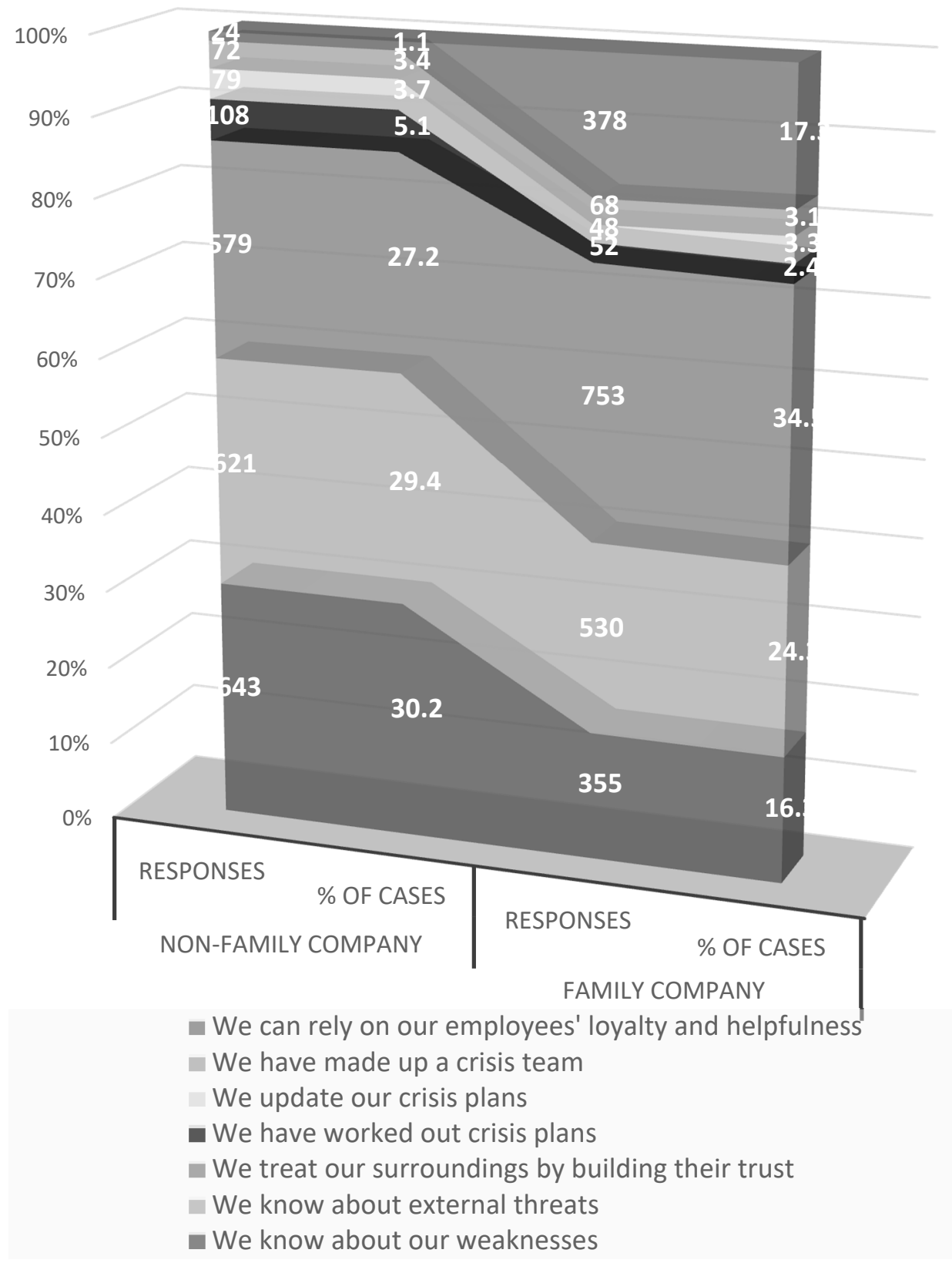

Figure 3. To what extent has your organization created the following conditions for coping with crises?

4.8.1. To What Extent has Your Organization Created the Following Conditions for Coping with Crises?

Non-family-owned businesses focused on the knowledge of their weaknesses and external threats; only three items have significant representation:

- We know about our weaknesses (643 respondents, $30.2 \%$ );

- We know about external threats (621 respondents, $29.4 \%$ );

- We treat our surroundings by building their trust (579 respondents, $27.1 \%$ ).

Family-owned businesses prioritise their external environment and then their internal environment: four items have significant representation, in order:

- We treat our surroundings by building their trust (753 respondents, 34.5\%);

- We know about external threats (530 respondents, 24.3\%); 
- We can rely on our employees' loyalty and helpfulness (378 respondents, $17.3 \%$ );

- We know about our weaknesses (355 respondents, $16.3 \%$ ).

Unlike non-FBs, FBs do not devote enough attention to internal analyses such as business weakness identification. In contracts to non-FBs however, FBs focus more on their external stakeholders and employees.

\subsubsection{Internal and Cross-Correlation}

To establish the results for FBs, select interlinks were chosen using internal and cross-correlation. In all instances, Kendall's ordinal correlation coefficient $\tau_{b}$ was utilised to express the extent of the interlinked relationships and their interdependencies. The extent of the interlinked dependency was tested using level $\alpha=0.05$ (important inter-dependency-expressed as one star following $\tau_{\mathrm{b}}$ in the below table) and $\alpha=0.01$ (very important inter-dependency-expressed as two stars). Considering that the correlation coefficient is paired and symmetrical, the results of the analysis are depicted using the so-called Fuller's triangle. In the resulting graphical representation (see below), the rows omit the first item of the question responses (i.e., We know about our weaknesses) and the columns omit the last item of the responses (i.e., We can rely on our employees' loyalty and helpfulness). Important inter-dependencies and correlations are highlighted (see Table 8).

Table 8. To what extent has your organization created the following conditions for coping with crises? The internal correlations between the responses.

\begin{tabular}{|c|c|c|c|c|c|c|}
\hline Fuller & $\begin{array}{c}\text { We Know } \\
\text { about Our } \\
\text { Weaknesses }\end{array}$ & $\begin{array}{l}\text { We Know } \\
\text { about } \\
\text { External } \\
\text { Threats }\end{array}$ & $\begin{array}{l}\text { We Treat Our } \\
\text { Surroundings } \\
\text { by Building } \\
\text { Their Trust }\end{array}$ & $\begin{array}{c}\text { We Have } \\
\text { Worked out } \\
\text { Crisis Plans }\end{array}$ & $\begin{array}{c}\text { We Update } \\
\text { Our Crisis } \\
\text { Plans }\end{array}$ & $\begin{array}{c}\text { We Have } \\
\text { Made up a } \\
\text { Crisis Team }\end{array}$ \\
\hline We know about external threats & $0.503^{* *}$ & & & & & \\
\hline $\begin{array}{l}\text { We treat our surroundings by } \\
\text { building their trust }\end{array}$ & 0.110 * & $0.205^{* *}$ & & & & \\
\hline We have worked out crisis plans & 0.085 & 0.065 & -0.010 & & & \\
\hline We update our crisis plans & 0.041 & 0.006 & -0.016 & $0.187^{* *}$ & & \\
\hline We have made up a crisis team & 0.330 & 0.022 & -0.024 & $0.153 * *$ & 0.101 * & \\
\hline $\begin{array}{l}\text { We can rely on our employees' } \\
\text { loyalty and helpfulness }\end{array}$ & 0.085 * & $0.132 *$ & $0.197^{* *}$ & -0.008 & 0.025 & -0.053 \\
\hline
\end{tabular}

Source: own research. * important inter-dependency. ${ }^{* *}$ very important inter-dependency.

The results are made up of two groups with mutually linked response items with significant positive correlations:

- We know about external threats, We treat our surroundings by building their trust, We know about our weaknesses, We can rely on our employees' loyalty and helpfulness;

- We have worked out crisis plans, We update our crisis plans, We have made up a crisis team. Two groups were created:

(a) items which make up informal attitudes towards crisis prevention;

(b) items representing a formalized crisis prevention approach.

The above statements can be verified using a factor analysis applied to the above response items (Table 9).

Utilising Kaiser's criteria, the analysis of the main components resulted in the identification of two significant factors in line with the assumption. Using the EQUAMAX method, the rotated solution identified the said four component items from the aforementioned group a) (informal approach) as comprising the first factor. The second factor was attributed the remaining components, outlined in group b (formal approach). The items "We have worked out crisis plans" and "We have made up a crisis team" show a weak influence on either factor (correlation with the factors is $<0.5$ ) whereas the influence is slightly higher on the second factor (b)). 
Table 9. To what extent has your organization created the following conditions for coping with crises? Factor analysis on the response items to: The resulting breakdown using factors.

\begin{tabular}{ccc}
\hline Rotated Component Matrix ${ }^{\mathbf{a}}$ & \\
\hline & Component \\
\cline { 2 - 2 } We know about external threats & $\mathbf{1}$ & $\mathbf{2}$ \\
\hline We treat our surroundings by building their trust & 0.554 \\
We know about our weaknesses & 0.671 \\
We can rely on our employees' loyalty and helpfulness & 0.742 \\
We have worked out crisis plans & 0.439 & 0.635 \\
We update our crisis plans. & 0.153 & 0.650 \\
We have made up a crisis team & 0.008 & 0.415 \\
\hline
\end{tabular}

Extraction Method: Principal component analysis. Rotation Method: EQUMAX with Kaiser normalization. a. Rotation converged in 3 iterations.

Source: own research.

\subsection{Hypothesis 7}

Hypothesis is based on the means used to manage the crisis. Many researchers list the environment in the family company as friendly and informal. Is this also true for crisis preparation?

Hypothesis 7a. Family-owned businesses rely on informal tools such as "Building up relationships with the surrounding environment" and "We treat our employees" in their crisis preparation to the same extent as non-family-owned businesses.

Hypothesis 7b. Family-owned businesses rely on informal tools such as "Building up relationships with the surrounding environment" and "We treat our employees" more than non-family-owned businesses.

The size of both samples is much greater than 50 and the selective shares do not result in any significant small or large values. Regarding H7a's validity, it can be assumed that the test statistics have an asymptotic normalized standard difference $Z$.

$$
\begin{gathered}
\mathrm{Z}=\frac{p_{1-} p_{2}}{\sqrt{p^{*}} \times(1-p) \times\left(\frac{1}{n_{1}}+\frac{1}{n_{2}}\right)} \\
\mathrm{p}^{*}=\frac{n_{1} p_{1}+n_{2} p_{2}}{n_{1}+n_{2}}
\end{gathered}
$$

where $n_{1,2}$-sample size, i.e., count of all responses, $p_{1,2}$-relative frequency of positive responses; critical field $(W)$ on the materiality level $(\alpha) 0.05$, where Hypothesis null is rejected and the alternative Hypothesis one is accepted.

After inputting values into the formula, the following value was calculated: $\mathrm{Z}=-23.4$

$\mathrm{W}=\left(-\infty,-\mathrm{Z}_{0.95}\right), \mathrm{W}=(-\infty,-1.645)$.

Conclusions

Based on the above, the following conclusion can be drawn: $Z \in W$, i.e., Hypothesis null (Family-owned businesses rely on informal tools in their crisis preparation to the same extent as non-family-owned businesses) can be rejected.

Hypothesis 7-Family-owned businesses rely on informal tools in their crisis preparation more than non-family-owned businesses-is accepted. 


\section{Discussion}

Almost the same number of respondents took part in the research from non-family-owned businesses (1118) as from family-owned businesses (1148). The vast majority of businesses from both groups were established in the 1990s, employed up to 50 employees ( $91 \%$ for family-owned businesses) and reached an annual turnover of CZK 5-20 million, i.e., 190,000-800,000 €.

Over one third of the respondents in each group (FBs and non-FBs) have been through a crisis situation which threatened the existence of their business. Over $70 \%$ of respondents in each group were motivated to implement measures to prevent future crises from occurring (Table 10).

Table 10. Table depicting the percentile and total count of responses per each group.

\begin{tabular}{cccccccc}
\hline & $\begin{array}{c}\text { Type of the } \\
\text { Company }\end{array}$ & $\begin{array}{c}\text { Have You Already } \\
\text { Solved Very Serious } \\
\text { Problems? }\end{array}$ & $\begin{array}{c}\text { Has the Crisis Made } \\
\text { You Ready to Cope with } \\
\text { Future Crisis? }\end{array}$ & $\begin{array}{c}\text { Do You Consider } \\
\text { Preparing for Crises } \\
\text { Important? }\end{array}$ \\
\hline \multirow{5}{*}{ definitely not } & Non-FB & $\%$ & total & $\%$ & total & $\%$ & total \\
& FB & 13.2 & 147 & 7.6 & 51 & 0 & 0 \\
rather not & Non-FB & 26.5 & 178 & 6.6 & 49 & 1.6 & 18 \\
rather yes & FB & 19.4 & 296 & 18.5 & 125 & 14.1 & 158 \\
definitely yes & Non-FB & 21.0 & 228 & 20.6 & 153 & 16.6 & 190 \\
& FB & 26.8 & 308 & 47.6 & 321 & 38.1 & 426 \\
& Non-FB & 39.4 & 440 & 26.4 & 269 & 41.6 & 478 \\
& FB & 37.8 & 434 & 36.5 & 271 & 47.8 & 534 \\
\hline
\end{tabular}

Source: own research.

Responses to open-ended questions can be categorized into several areas. In the first area, and also the least well represented, the respondents stated they had enough contracts and orders despite the crisis. The second area generally comprises the opinion that economic crises are the result of political crises and are mainly a matter for the media. The third area was the broadest. The respondents were of the opinion that crises are not predictable, their occurrence cannot be prevented, same types of crises will not re-occur and, therefore, it is not necessary to implement preventive measures or prepare for crises in any way.

In the introduction sections of the paper, the authors identified some research works which were of interest or supporting widely held theories regarding family-owned businesses. These were put in the context of preparing for the crisis. The supporting information was grouped into areas that have a direct or indirect link with preparation for the crisis as the tangible and intangible key factors of sustainability business: human resources, business performance and business resistance during the crisis, and stakeholders. Issues from these areas are reflected in the questionnaire, as well as the results from an informal meeting with business managers and owners. Now the authors present their merits in the creation of research questions for discussion.

- Research question 1: Are FBs more prepared for crises, so they overcome them more often than non-FBs?

The strongest positive argument is of a personal nature: most families consider their businesses a source of their livelihood [19], they are bound by strong blood bonds [8], there is an effort to pass the business on to the next generation $[8,19,45]$. Personal features are associated with financial support for the business: start-up and development are most often financed by family funds $[8,27,45]$. The effort to successfully hand over the company to the successor generation is connected with maximizing the company's long-term value [36,45]. An important feature that non-FBs do not have is socioemotional wealth goals $[14,15]$. If individual items of SEW are of high value, family cohesion and adaptability can significantly affect the sustainability of their business [30-32].

Authors consider some factors to be ambiguous. They can be both an advantage and a disadvantage for preparing for a crisis: 
FBs have an aversion to risk $[19,20]$. Is investing into crisis management appropriate to justify the asset spend? Afterall, the spent assets do not represent tangible value and do not generate income for the business. Which is the greater risk: the potential waste of funds and other assets spent on building up preventive measures which may fail in the end, or the risk of saving the funds in the short term at the expense of not preparing for a crisis and thus not mitigating the potential impact? Will the dream of passing the business onto future generations trump the inconvenience of making non-productive investments into preventive measures? The question is to what extent the aversion to risk will affect the attitude of top management towards preparation for crises.

Non-economic and family-oriented goals [35]. Non-economic goals can indicate greater responsibility to stakeholders. Family-oriented goals can give the family greater resources or other benefits. On the other hand, they can have negative effect on businesses' profitability, especially during the acute phase of crisis [25]. Both types can contribute to an irresponsible approach to business. Unbalanced family and business goals may be the very cause of the crisis $[11,45]$.

Blending of family and business. Loyalty of family members cannot be guaranteed. Family members may have different interests $[8,46]$ that may impair businesses' profitability [25], performance [17] or even the very existence of the business $[8,45,46]$.

However, despite this, it is generally possible to think about greater efforts by FBs for economic sustainability, the pursuit of survival. This means that FBs are preparing for crises. Thanks to prevention, the crisis in their businesses may not occur at all.

Answer 1: FBs do not prepare for crises with such quality or intensity to avoid them more often than non-FB enterprises. FBs applied crisis management and faced serious issues threatening the businesses' existence to the same extent as non-FBs (see Hypothesis 1).

- Research question 2: If they have experienced a crisis, are FBs more motivated to prepare for crises?

There may be a situation where the company is in crisis because the preparation for the crisis did not exist or was not sufficient. What happens during and after the successful survival of the crisis? Will owners realize the threat to the value of their business for the future? Or will they say-we have survived the crisis, we have an excellent, stable business, we do not have to worry about the future?

This wrong belief can occur in many owners [44]. Some researches point to owners' responsible attitude during crisis in the search for liquid resources [26], mobilizing resources [24], better economic performance during crisis $[23,24]$. Willingness to use family funds increases the ability to cope with a crisis $[27,29]$. This chance does not exist for non-family businesses.

Answer 2: Nor specific features, such as family ownership or the future of the family, do not influence the owners to prepare for future crises more intensively than non-FB. FBs attitudes towards future crisis prevention following the experience of one or more crises are the same as those of non-FBs (see Hypothesis 2).

- $\quad$ Research question 3: Do FBs consider preparing for a crisis to be more important than non-FBs?

A family business is often the only source of livelihood for the whole family $[19,46]$. Other pros and cons are already mentioned above. In theory, it is in the interest of the whole family to protect the source of their livelihood. However, other (personal) interests may prevail [8,45,46].

Answer 3: Even understanding the family business as a source of livelihood did not force their owners to evaluate the importance of crisis preparedness more than non-FB did. FBs consider preparing for a crisis as much as non-FBs (see Hypothesis 3).

- Research question 4: Do FBs care about employees better in times of crisis than non-FBs? Does this happen in times of crisis when cost reduction occurs?

A number of authors stated that FBs tend to care more about their employees and their needs and development $[8,45,46]$. The owners evaluate the importance of fair access to all employee-family 
and non-family [13]. The care of employees, fair access to them are also enshrined in family values, vision and purpose [9] and FB rules and codex $[45,46]$. The owners are aware that lack of interest in employees reduces perceptions of fairness, resulting in low economic and noneconomic outcomes for the firm [11]. They realize that fairness and equal access in the employment field bring employee loyalty [12].

On the other hand, in times of crisis, reducing personnel costs (redundancies) is the first way to reduce overall costs. Is it possible to agree with the findings that FBs in times of crisis tend to maintain the number of employees while they reduce their assets [29]?

Answer 4: The access to employees is not different in FBs and non-FBs in times of crisis. Both FBs and non-FBs have been noted to have identical attitudes towards employee dismissal as a means of saving funds when dealing with crises (see Hypothesis 4). The economic needs of the business appear to outweigh the employers' humanitarian approach. This finding is not in conformity with the research of [29]. On the other hand, $17.3 \%$ of FBs stated they can rely on their employees' loyalty and helpfulness at times of crisis. Only $1 \%$ of non-FBs made that same statement. Therefore, it is safe to say that FBs rely more than non-FBs on their employees' loyalty (the difference in the response count is negligible).

- Research question 5: Do the costs of preparing for crises deter FBs as much as non-FBs?

This question emerged from a meeting with owners and managers. Businesses which refuse to invest into crisis prevention measures have a number of reasons. It is up to the managers themselves to find whether this is really a reason or an excuse. The high costs of creating and implementing preventive measures, where there is no guarantee that they will work when a crisis actually occurs, were most frequently mentioned as a reason not to proceed with prevention.

Answer 5: There is no difference; both FBs and non-FBs stated high cost to the same extent (see Hypothesis 5). On the other hand, non-FBs are significantly not afraid of a crisis (due to a strong market position, strong strategic partner, healthy finances, etc.)

- $\quad$ Research question 6: Do FB managers have time to prepare preventive measures?

This question emerged from a meeting with owners and managers, too. Some of them say we want to prepare for the crisis, but we are not doing it because they themselves need to find out when they will forgo their excuses and actually start preparing for a crisis. The most frequently mentioned reason was the lack of time to deal with this issue. In their defense, it must be stated that they were mostly small business managers. They have more functions in the company and are overwhelmed with operational matters (however, this is not a justification).

Answer 6: There is no difference, both FBs and non-FBs stated lack of time to the same extent (see Hypothesis 6). Lack of experts and lack of finance are also represented to the same extent.

- $\quad$ Research question 7: Does family and informality prevail even in preparation for crises?

The environment in the family company is often mentioned as informal [8,46]. Informal, family-friendly environments are presented in the annual reports or on websites of FBs. FBs often realize late that as the company grows, it is necessary to adopt the formalized side of activities. The lack of a formalized structure can be a source of crisis at some point in the company's development.

A formal approach in the process of preparing for crises means having formalized documents, resources, teams, procedures for this area.

Elements of an informal approach include, but are not limited to, the following. FBs have a more ethical attitude towards their stakeholders, both internal and external, i.e., employees and environment [33]; they communicate with them [34]. FBs take into account their values in the values and visions of the family and business [9], their objectives in FB activities [8,45]. This is also due to the existence of a number of non-economic goals [35]. It can be assumed that the social approach of FBs is 
also reflected in their preparation processes to deal with crises and their behavior during the crisis itself $[34,36]$. They are interested in their employees, create their loyalty on the basic of justice and fair access [13]. However, they are little aware that a precondition for this justice are formalized policies for non-family as well as family members [11,12].

Answer 7: The informal approach of FBs is prevalent in the process of preparing for crises, too. FBs rely more on informal preparation means such as building up relationships with their surrounding environment and maintaining relationships with their external (e.g., business partners, residents, institutions, banks, etc.) and internal (e.g., employees) stakeholders rather than on formal approaches such as writing formal crisis plans and creating crisis teams (see Hypothesis 7). FBs treat their employees and surrounding environment in a way so as to build their trust, which is important at times of crisis.

\section{Conclusions}

Authors' hypotheses made at the beginning of the paper and their rejection/acceptation:

Hypothesis 1-Family-owned businesses face crisis situations less frequently than non-family businesses-rejected.

Hypothesis 2-Having once experienced a crisis situation, FBs are more motivated than non-FBs to improve the preparation process for future crises-rejected.

Hypothesis 3-Family-owned businesses consider preparing to prevent future crises more important than non-family-owned businesses-rejected.

Hypothesis 4-Family-owned businesses dismiss employees in times of crisis less often than non-family businesses-rejected.

Hypothesis 5-High costs of implementing measures for preparation for crises is an equally common reason both for family and non-family-owned businesses that do not consider crisis preparation important-accepted.

Hypothesis 6-Lack of time is a factor for non-preparation for crisis to the same extent both for FBs and non-FBs-accepted.

Hypothesis 7-Family-owned-businesses rely on informal tools in their crisis preparation more than non-family-owned businesses-accepted.

On the basis of the results, the answers to the research questions and tested hypotheses, it can be concluded that, as far as economic sustainability is concerned, family businesses do not put in more effort than non-family businesses; Czech family-owned businesses are not more responsible in the area of crisis prevention than Czech non-family-owned businesses.

Economic sustainable business is a great challenge for all types of business without distinction of owners or size. The not-very-flattering results for Czech FBs may result from the following limitation. Comparisons with countries that have not experienced the constraints of "building socialism", and where the history of family business is longer, could yield very interesting results.

This research has the following limitations: (1) Unsubscribed documents in the Collection of Documents-businesses are reluctant to upload their financial statements to the Collection of Documents, even if it is their duty. The missing data are quite significant (more than one third of total entities) which could have affected the results. (2) Focus only on the manufacturing industry. In other areas, the representation of family businesses may be different. (3) Inaccurate definition of family enterprise-identification by the same surname, which does not necessarily mean that they are a family member, or vice versa - a family member may have a different surname. (4) Thanks to the communist period, family business in the Czech Republic is still building a tradition. On the other hand, this period of birth or rebirth of family business can be a platform for time comparison in the future.

The authors are convinced that the results of the research will contribute to a better understanding of the peculiarities of family firms across different areas compared to their non-family counterparts. Authors also expect the research to contribute to generating discussion about family businesses not only in the Czech Republic but also in other post-communist countries with similar political 
developments. In addition, it is anticipated that the research results will help to stimulate support from state institutions and legislation in the research area. Furthermore, the article will contribute to the discussion and reflection on ways and approaches to ensuring a sustainable business, regardless of the type of business.

At the same time, the results will provide background data for further, deeper elaboration of the individual areas studied (e.g., HR, performance etc.), either independently or via qualitative research and evaluation of their interactions. The questions formulated in the text of the first part of the article are also a theme for further research, to which the authors call.

Author Contributions: Conceptualization, M.M. and P.H.; Data curation, M.M. and V.F.; Formal analysis, V.F.; Investigation, M.M. and P.H.; Methodology, M.M. and P.H.; Validation, M.M.; Writing-original draft, M.M.; Writing-review \& editing, P.H. All authors have read and agreed to the published version of the manuscript.

Funding: This work was supported by the Student Grand Competition (SGS) in the Technical university of Ostrava, Faculty of Economics [SGS 2020/33].

Conflicts of Interest: The authors declare no conflict of interest.

Appendix A

Table A1. Questionnaire.

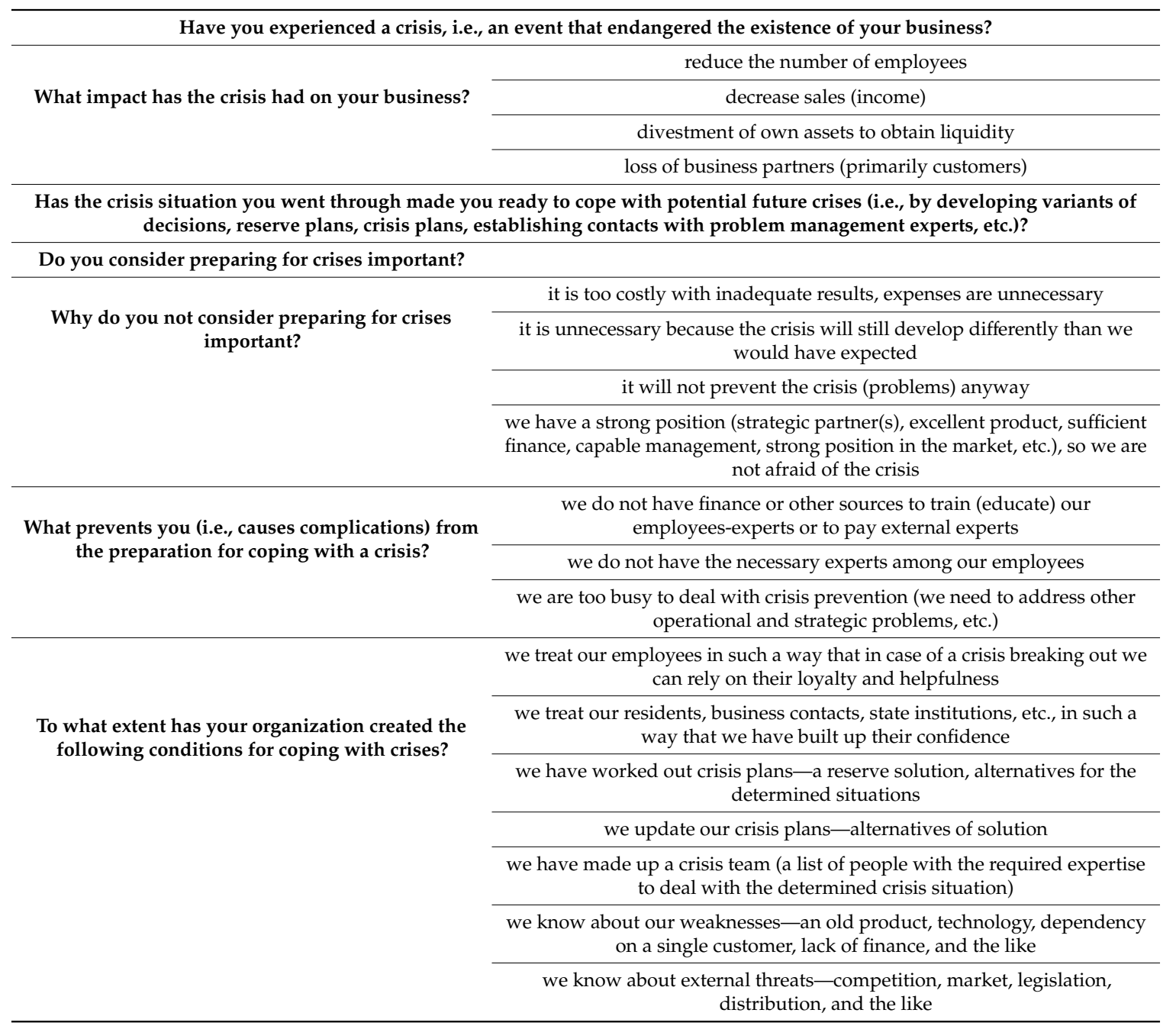

Source: authors. 


\section{References}

1. Davis, J.A. Definitions and Typologies of the Family Business; Harvard Business School: Boston, MA, USA, 2001.

2. Mandl, I. Overview of Family Business Relevant Issues. Final Report. 2008. Available online: http://www.familienunternehmen.de/media/public/pdf/projekte-veranstaltungen/expertengruppefamilienunternehmen/stiftungfamilienunternehmen_expertengruppe-familienunternehmen_ abschlussbericht.pdf (accessed on 3 June 2018).

3. Hubler, T. The Soul of Family Business: A Practical Guide to Family Business Success and a Loving Family; Lilja Press: Minneapolis, MN, USA, 2018.

4. Kulhavý, V. Strategicky na Udržitelný Rozvoj v Podniku (Strategic Sustainable Development Planning in a Company); Economia: Praha, Czech Republic, 2007.

5. Shrivastava, P. Crisis theory/practice: Towards a sustainable future. Ind. Environ. Crisis Quaterly 1993, 7, 23-42. [CrossRef]

6. Hart, P.; Heyse, L.; Boin, A. New trends in crisis management practice and crisis management research: Setting the agenda. J. Conting. Crisis Manag. 2001, 9, 181-188. [CrossRef]

7. Bertrand, R.; Lajtha, C. A new approach to crisis management. J. Conting. Crisis Manag. 2012, 10, 181-191.

8. Aronoff, C.; Ward, J. Family Business Governance: Maximizing Family and Business Potential; Palgrave Macmillan: New York, NY, USA, 2016.

9. Schuman, A.M.; Sage-Hayward, W.; Ransburg, D. Human Resources in the Family Business: Maximizing the Power of Your People; Palgrave Macmillan: London, UK, 2016.

10. Ransburg, D.; Sage-Hayward, W.; Schuman, A.M. Managing the Complexity of Human Resources in Family Firms. 2016. Available online: https://www.thefbcg.com/managing-the-complexity-of-human-resources-infamily-firms-/ (accessed on 6 March 2019).

11. Daspit, J.J.; Madison, K.; Barnett, T.; Long, R.G. The emergence of bifurcation bias from unbalanced families. Hum. Resour. Manag. Rev. 2018, 28, 18-32. [CrossRef]

12. Sharma, E. HR issues and intervention model for family business. Int. J. Bus. Econ. Manag. Res. 2012, 2, 288-297.

13. Schuman, A.; Ward, J. Family Education for Business-Owning Families: Strengthening Bonds by Learning Together; Palgrave Macmillan: London, UK, 2017.

14. Dou, J.; Wang, N.; Su, E.; Fang, H.; Memili, E. Goal complexity in family firm diversification: Evidence from China. J. Fam. Bus. Strategy 2020, 11, 1-12. [CrossRef]

15. Cleary, P.; Quinn, M.; Moreno, A. Socioemotional wealth in family firms: A longitudinal content analysis of corporate disclosures. J. Fam. Bus. Strategy 2019, 10, 119-132. [CrossRef]

16. San-Martin-Reyna, J.M.; Duran-Encalada, J.A. The Relationship among Family Business, Corporate Governance and Firm Performance: Evidence from the Mexican stock Exchange. J. Fam. Bus. Strategy 2012, 3, 106-117. [CrossRef]

17. Lin, H.; Chen, H. Family Management and Firm Value: The Moderating Influence of Founder-CEO and Outside Directorship. Int. Res. J. Financ. Econ. 2012, 85, 40-54.

18. Zellweger, T. Managing the Family Business: Theory and Practice; Edward Edgar: Cheltenham, UK, 2017.

19. Molly, V.; Laveren, E.; Deloof, M. Family Business Succession and Its Impact on Financial Structure and Performance. Fam. Bus. Rev. 2010, 23, 131-147. [CrossRef]

20. Craigh, J.B.; Moores, K. Leading a Family Business: Best Practices for Long-Term Stewardship; Praeger: Westport, Ireland, 2017.

21. Holt, D.T.; Pearson, A.W.; Carr, J.C. Family Firm(s) Outcomes Model: Structuring Financial and Nonfinancial Outcomes Across the Family and Firm. Fam. Bus. Rev. 2016, 30, 182-202. [CrossRef]

22. Michiels, A.; Molly, V. Financing Decisions in Family Businesses: A Review and Suggestions for Developing the Field. Fam. Bus. Rev. 2017, 30, 369-399. [CrossRef]

23. Schambers, A.L. Avoid unexpected surprises with self-analysis. Grand Rapids Bus. J. 2018, 36, 15.

24. Allouche, J.; Amann, B.; Jaussaud, J.; Kurashina, T. The Impact of Family Control on the Performance and Financial Characteristics of Family Versus Nonfamily Businesses in Japan: A Matched-Pair Investigation. Fam. Bus. Rev. 2008, 21, 315-329. [CrossRef]

25. Amann, B.; Jaussaud, J. Family and non-family business resilience in an economic downturn. Asia Pac. Bus. Rev. 2012, 18, 203-223. [CrossRef] 
26. Cesaroni, F.M.; Resta, M.; Sentuti, A. Family Businesses, Innovation and Performance During an Economic Crisis: The SOM Methodology. In Proceedings of the European Conference on Innovation \& Entrepreneurship, Paris, France, 21-22 September 2017; pp. 686-695.

27. Zhou, H.; He, F.; Wang, Y. Did family firms perform better during the financial crisis? New insights from the S\&P 500 firms. Glob. Financ. J. 2017, 33, 88-103.

28. Bauweraerts, J.; Colot, O. How do Family Firms Deal with the Crisis? Int. Adv. Econ. Res. 2013, 19, 313-314. [CrossRef]

29. Gallizo, J.L.; Moreno, J.; Sánchez, L. Quines empreses han aguantat millor la crisi, les empreses familiars o les no familiars? Intagible Cap. 2014, 10, 766-797.

30. Casillas, J.C.; Barbero Navarro, J.L.; Moreno Menéndez, A.M. Turnaround Strategy and ownership structure in declining firms: Diferences between family and non-family businesses. Rev. Empresa Fam. 2013, 3, 7-20.

31. Olson, P.D.; Zuiker, V.S.; Danes, S.M.; Stafford, K.; Heck, R.K.Z.; Duncan, K.A. The impact of the family and the business on family business sustainability. J. Bus. Ventur. 2003, 18, 639-666. [CrossRef]

32. Kepner, E. The family and the firm: A coevolutionary perspective. Fam. Bus. Rev. 1991, 4, 445-461. [CrossRef]

33. Poech, A.; Kriwanek, F. Integrative ethics management systems in family firms: An exploratory approach. In Proceedings of the NeuroPsychoEconomics Conference Proceedings, Munich, Germany, 26-27 May 2011; p. 54 .

34. Klimsza, L.; Lokaj, A. The Global Culture and Economical Values: The Corporation Responsibility in the Fragmentary Global Culture. In Proceedings of the ICABR 2014, Talco, Chile, 6-10 October 2014; pp. 426-435.

35. Papalová, M. Media impact on crisis communications. In Proceedings of the International Scientific Conference on Marketing Identity—Digital Life, Trnava, Slovakia, 10-11 December 2015; pp. 448-459.

36. McCormick, D.P. Family Inc.: Using Business Principles to Maximize Your Family's Wealth; Wiley: Hoboken, NJ, USA, 2016.

37. Nacht, J. Champions and Champion Families: Developing Family Leaders to Sustain the Family Enterprise; Family Business Consulting Group: Chicago, IL, USA, 2018.

38. Economic Impact of Family Businesses-A Compilation of Facts. Tharawat Magazine, 1 June 2016.

39. Polit, D.F.; Beck, C.T. The Content Validity Index: Are You Sure You Know What's Being Reported? Critique and Recommendations. Res. Nurs. Health 2006, 29, 489-497. [CrossRef] [PubMed]

40. Ayre, C.; Scally, A. Critical values for Lawshe's Content Validity Ratio. Meas. Eval. Couns. Dev. 2013, 47, 79-86. [CrossRef]

41. Kline, P. The Handbook of Psychological Testing; Routledge: London, UK, 1993.

42. Eisinga, R.; Te Grotenhuis, M.; Pelzer, B. The reliability of a two-item scale: Pearson, Cronbach or Spearman-Brown? Int. J. Public Health 2013, 58, 637-642. [CrossRef] [PubMed]

43. Friedrich, V. Postojové a Hodnoticí Škály v Marketingu a Managementu. Vybrané Statistické Metody a Aplikace (Attitude and Evaluation Scales in Marketing and Management. Selected Statistical Methods and Applications); VSB-Technical University of Ostrava: Ostrava, Czech Republic, 2017.

44. Mitroff, I.I.; Pauchant, T.C.; Finney, M.; Pearson, C. Do (some) organizations cause their own crises? The cultural profiles of crisis-prone VS. crisis-prepared organizations. Organ. Environ. 1989, 3, 269-283. [CrossRef]

45. Carlock, R.S.; Ward, J.L. Strategic Planning for the Family Business; Palgrave MacMillan: London, UK, 2001.

46. Mikušová, M. Family Business; VSB-Technical University of Ostrava: Ostrava, Czech Republic, 2018.

(C) 2020 by the authors. Licensee MDPI, Basel, Switzerland. This article is an open access article distributed under the terms and conditions of the Creative Commons Attribution (CC BY) license (http://creativecommons.org/licenses/by/4.0/). 